\title{
Groundwater Quality in the Basin and Range Basin-Fill Aquifers, Southwestern United States
}

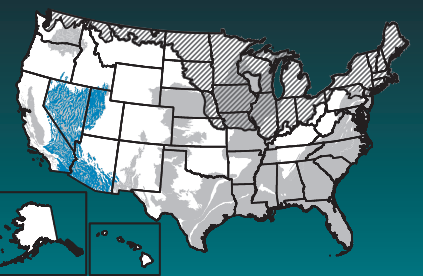

Groundwater provides nearly $\mathbf{5 0}$ percent of the Nation's drinking water. To help protect this vital resource, the U.S. Geological Survey (USGS) National Water-Quality Assessment (NAWQA) Project assesses groundwater quality in aquifers that are important sources of drinking water (Burow and Belitz, 2014). The Basin and Range basin-fill aquifers constitute one of the important areas being evaluated.

\section{Background}

The Basin and Range basin-fill aquifers underlie an area of 148,000 square miles in Nevada, California, Arizona, Utah, and adjacent States. The aquifers are a substantial source of groundwater for public supply, ranking fourth in the Nation for this use and providing about 1 billion gallons per day; the aquifers are also ranked tenth for domestic-supply use at about 64 million gallons per day and ranked fourth for irrigation use at about 4.5 billion gallons per day (Arnold and others, 2016). Land use overlying these aquifers is mostly undeveloped and rangeland (about 90 percent), with a relatively small amount of agricultural (about 4 percent) or urban (about 3 percent) land. The overlying land area has a population of about 12 million people. Urban areas within the boundaries of the aquifers include Salt Lake City, Reno, Las Vegas, and Phoenix.

The Basin and Range basin-fill

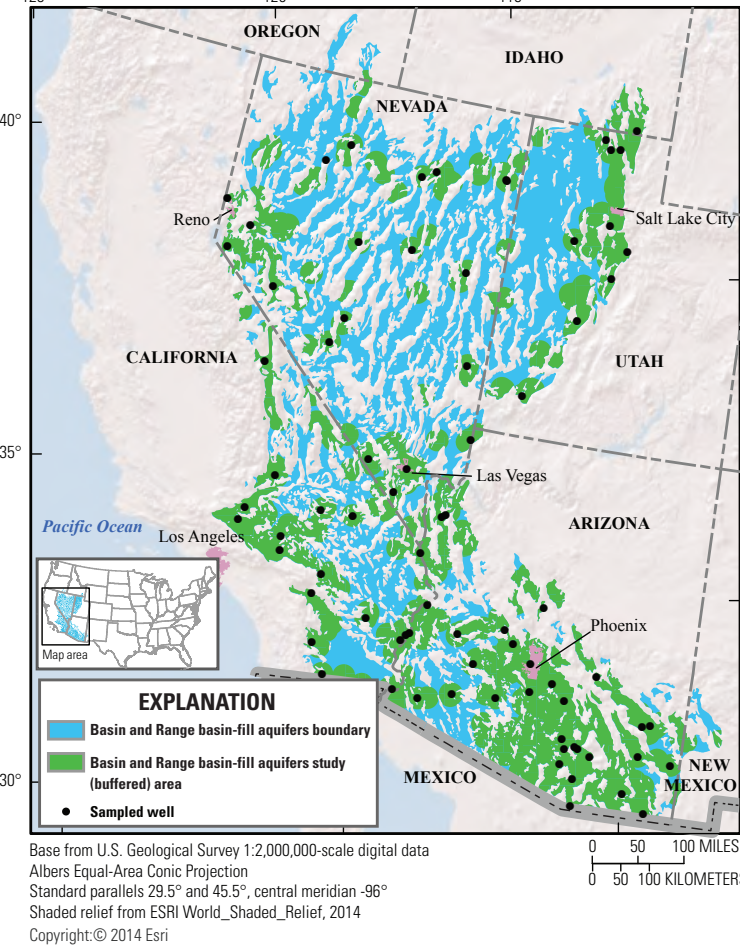
aquifers consist primarily of sedimentfilled basins separated by mountain ranges (Anning and Konieczki, 2005; Thiros and others, 2014). Basin-fill deposits range from about 1,000 to 5,000 feet thick in many basins, but are thicker in some basins (Robson and Banta, 1995). Groundwater is mostly unconfined (Anning and Konieczki, 2005). Most precipitation in the arid region is lost to evapotranspiration (Robson and Banta, 1995). Recharge from infiltration of mountain streams and inflow from fractured bedrock typically enters the aquifers along mountain fronts (Robson and Banta, 1995). Irrigation water and seepage from rivers also provide recharge in some basins (Thiros and others, 2014) Evaporation is the largest natural discharge component. In some basins, groundwater withdrawals for irrigation or public supply have altered natural groundwater-flow directions (Thiros and others, 2014).

Groundwater quality in the Basin and Range basin-fill aquifers was evaluated by sampling 78 public-supply wells that were spatially distributed across the aquifers. Parts of the region are sparsely populated, and public-supply wells are not evenly distributed. Consequently, the study area was delineated by placing 20-kilometer (12.4 mile) buffers around existing public-supply wells; an equal-area grid was then defined within the buffered area. For this discussion, we define the study area as the depth zone used for public supply in the Basin and Range basin-fill aquifers in the buffered area. Water-quality data collected from the spatially distributed wells (31 in Arizona, 17 in California, 1 in Idaho, 20 in Nevada, and 9 in Utah) are representative of water quality in the study area, following the approach described by Belitz and others (2010). This approach allows for the estimation of the percentage of the study area with concentrations that are high, moderate, and low with respect to constituent benchmarks. The accuracy of the estimates depends on the distribution and number of wells, not on the size of the area (Belitz and others, 2010). The wells ranged from 83 to 1,450 feet deep (averaging 575 feet deep) and were open to the aquifer across long depth intervals (averaging about 280 feet). Samples were analyzed for a large number of water-quality constituents derived from natural and human sources.

\section{Overview of Water Quality}
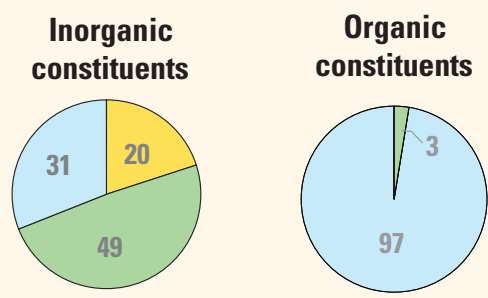

CONSTITUENT CONCENTRATIONS

High $\bigcirc$ Moderate $\bigcirc$ Low or not detected

Values are a percentage of the study area with concentrations in the three specified categories. Percentages might not sum to 100 because of rounding.

Principal Aquifer Studies are designed to evaluate groundwater used for public supply prior to any treatment. Groundwater quality is assessed by comparing concentrations to benchmarks established for drinking-water quality. Benchmarks and definitions of high, moderate, and low relative concentrations are discussed in the inset box on page 3

Many inorganic constituents are naturally present in groundwater. The concentrations of inorganic constituents can be affected by natural processes as well as by human activities. One or more inorganic constituents with humanhealth benchmarks were detected at high concentrations in about 20 percent of the study area and at moderate concentrations in about 49 percent.

Organic constituents derived from human activities are found in household, business, industrial, and agricultural products. They can enter the environment through normal usage, spills, or improper disposal. Organic constituents were not detected at high concentrations in the study area. One or more organic constituents with human-health benchmarks were detected at moderate concentrations in about 3 percent of the study area. 


\section{Results: Groundwater Quality at the Depth Zone Used for Public Supply in the Basin and Range Basin-Fill Aquifers}

\section{INORGANIC CONSTITUENTS}

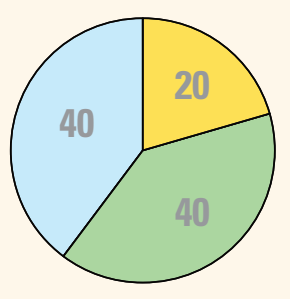

\section{Trace elements and major and minor ions}
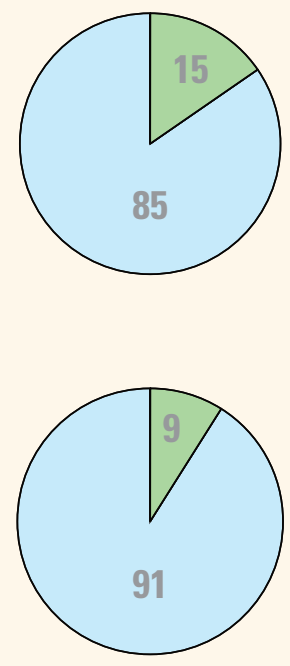

\section{Radioactive constituents}

\section{Nutrients}

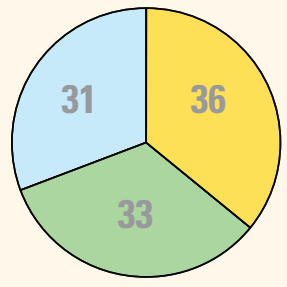

\section{Inorganic Constituents with Human-Health Benchmarks}

Trace elements and major and minor ions are naturally present in the minerals of rocks, soils, and sediments and in the water that comes into contact with those materials. Samples were analyzed for 34 trace elements and major and minor ions, of which 19 have human-health benchmarks. Constituents from this group were detected at high concentrations in about 20 percent of the study area (the depth zone used for public supply) and at moderate concentrations in about 40 percent. Arsenic was the trace element most frequently detected at high concentrations (13 percent) and at moderate concentrations (35 percent). Fluoride was detected at high concentrations in about 7 percent of the study area. Manganese, molybdenum, and uranium each were measured at high concentrations in about 3 percent of the study area. Fluoride, manganese, molybdenum, and strontium each were measured at moderate concentrations in 5 to 6 percent of the study area. Uranium was measured at moderate concentrations in 1 percent of the study area.

Radioactivity is the release of energy or energetic particles during the spontaneous decay of unstable atoms. Humans are continuously exposed to small amounts of natural radioactivity. Most of the radioactivity in groundwater comes from the decay of isotopes of uranium and thorium that are naturally present in minerals in aquifer materials. Samples were analyzed for eight radioactive constituents, of which four have human-health benchmarks. No radioactive constituents were present at high levels in the study area; moderate levels of radioactive constituents, mainly gross alpha activity or radon, were measured in about 15 percent of the study area.

Nutrients are naturally present at low concentrations in groundwater; high and moderate concentrations (relative to human-health benchmarks) generally result from human activities. Samples were analyzed for five nutrients, of which two have human-health benchmarks. Common sources of nutrients, aside from soils, include fertilizer applied to crops and landscaping, seepage from septic systems, and human and animal waste. Nutrients were not present at high concentrations in the study area. Nitrate was the only nutrient detected at moderate concentrations, which were measured in about 9 percent of the study area. Many of the moderate concentrations were in the southern part of the study area, the Sonoran Desert area of southwestern Arizona and southeastern California, where nitrogen fixation by desert legumes could contribute to naturally elevated nitrate concentrations (Walvoord and others, 2003).

\section{Inorganic Constituents and Field Measurements with Non-Health-Based Benchmarks}

(Not included in water-quality overview charts shown on the front page)

Some constituents affect the aesthetic properties of water, such as taste, color, and odor, or can create nuisance problems, such as staining and scaling. The benchmarks used for these constituents were non-regulatory secondary maximum contaminant level (SMCL) benchmarks established for public drinking water. Some constituents, such as manganese and fluoride, have human-health benchmarks and SMCLs. Samples were analyzed for 11 constituents that have SMCLs. One or more of these were present at high concentrations or values relative to the SMCL in about 36 percent of the study area and at moderate concentrations in about 33 percent.

Total dissolved solids (TDS) concentration is a measure of the salinity of the groundwater based primarily on concentrations of ions, and all water naturally contains TDS as a result of the weathering and dissolution of minerals in rocks and sediments. Concentration of TDS can be high because of natural factors or as a result of human activities, such as applications to the land surface of road salt, fertilizers, or other chemicals in urban or agricultural areas. Most of the study area had high (32 percent) or moderate (36 percent) concentrations of TDS. In the Basin and Range basin-fill aquifers, elevated concentrations of TDS might reflect natural sources from mineral dissolution and evaporative concentration, as well as sources from human alterations of groundwater flow systems and excess irrigation water (Thiros and others, 2014). Chloride and sulfate were present at high concentrations in about 12 and 13 percent of the study area, respectively, and at moderate concentrations in 10 and 14 percent, respectively. Fluoride was present at high concentrations relative to the SMCL in about 12 percent of the study area, and at moderate concentrations in 8 percent.

Anoxic conditions in groundwater (low amounts of dissolved oxygen) can result in the release of iron and manganese in minerals to the groundwater. Manganese was present at high concentrations relative to the SMCL in about 8 percent of the study area. Iron was present at high concentrations relative to the SMCL in about 1 percent of the study area and at moderate concentrations in 3 percent.

In some areas of the Basin and Range basin-fill aquifers, the $\mathrm{pH}$ of the groundwater was not in the SMCL range of 6.5 to 8.5. The $\mathrm{pH}$ was greater than 8.5, which is alkaline, in about 6 percent of the study area. 


\section{Results: Groundwater Quality at the Depth Zone Used for Public Supply in the Basin and Range Basin-Fill Aquifers}

\section{ORGANIC CONSTITUENTS}

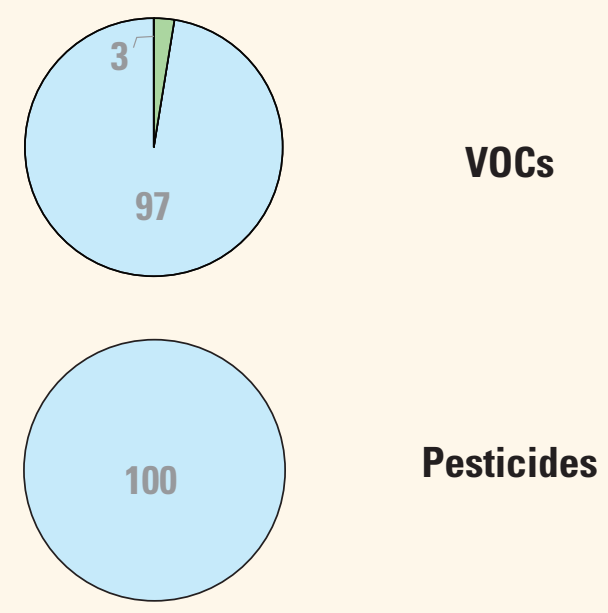

\section{Volatile Organic Compounds with Human-Health Benchmarks}

Volatile organic compounds (VOCs) are present in many household, commercial, industrial, and agricultural products and are characterized by their tendency to volatilize (evaporate). Samples were analyzed for 90 VOCs, of which 38 have human-health benchmarks. No VOCs were detected at high concentrations; VOCs were detected at moderate concentrations in 3 percent of the study area. Compounds detected at moderate concentrations were the fumigant 1,2-dichloropropane and the solvent tetrachloroethylene.

\section{Pesticides with Human-Health Benchmarks}

Pesticides, including herbicides, insecticides, and fumigants, are applied to crops, gardens and lawns, around buildings, and along roads to help control unwanted vegetation (weeds), insects, fungi, and other pests. Samples were analyzed for 227 pesticide compounds (pesticides and their breakdown products), of which 119 have human-health benchmarks. Pesticide compounds were not detected at high or moderate concentrations in the study area.

\section{BENCHMARKS FOR EVALUATING GROUNDWATER QUALITY}

The USGS NAWQA Project uses benchmarks established for drinking water to provide context for evaluating the quality of untreated groundwater. The quality of water received by consumers can be different, because after withdrawal, groundwater may be treated prior to delivery. Federal regulatory benchmarks for protecting human health are used for this evaluation of water quality when available. Otherwise, non-regulatory human-health benchmarks and non-regulatory aesthetic benchmarks are used. Not all constituents analyzed have benchmarks and, thus, are not considered in this context. Out of 55 inorganic constituents and properties and 317 organic constituents, 24 and 157, respectively, have human-health benchmarks.

Concentrations are considered high if they are greater than a human-health benchmark (Toccalino and others, 2014) or SMCL. For inorganic constituents, concentrations are moderate if they are greater than one-half of a benchmark. For organic constituents, concentrations are moderate if they are greater than one-tenth of a benchmark; this lower threshold is used because organic constituents are generally less prevalent and have lower concentrations relative to benchmarks than inorganic constituents (Toccalino and others, 2004).

\section{Benchmark Type and Value for Selected Constituents}

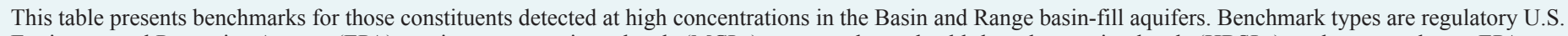

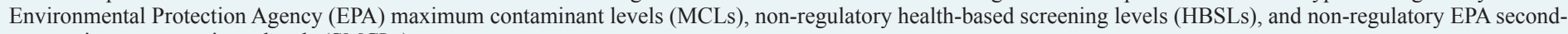
ary maximum contaminant levels (SMCLs).

[Abbreviations: ppb, parts per billion (ppb) or micrograms per liter $(\mu \mathrm{g} / \mathrm{L})$; ppm, parts per million $(\mathrm{ppm})$ or milligrams per liter $(\mathrm{mg} / \mathrm{L})]$.

\begin{tabular}{|c|c|c|c|c|c|}
\hline \multirow{2}{*}{ Constituent } & \multicolumn{2}{|c|}{ Benchmark } & \multirow{2}{*}{ Constituent } & \multicolumn{2}{|c|}{ Benchmark } \\
\hline & Type & Value & & Type & Value \\
\hline Arsenic & MCL & $10 \mathrm{ppb}$ & Chloride & SMCL & $250 \mathrm{ppm}$ \\
\hline Fluoride & MCL & $4 \mathrm{ppm}$ & Fluoride & SMCL & $2 \mathrm{ppm}$ \\
\hline Manganese & HBSL & $300 \mathrm{ppb}$ & Manganese & SMCL & $50 \mathrm{ppb}$ \\
\hline Molybdenum & HBSL & $40 \mathrm{ppb}$ & Sulfate & SMCL & $250 \mathrm{ppm}$ \\
\hline Uranium & MCL & $30 \mathrm{ppb}$ & Iron & SMCL & $300 \mathrm{ppb}$ \\
\hline Total dissolved solids (TDS) & SMCL & $500 \mathrm{ppm}$ & $\mathrm{pH}$ & SMCL & $6.5-8.5$ \\
\hline
\end{tabular}




\section{Spatial Distribution of Constituent Concentrations Above Human-Health Benchmarks}

Inorganic constituents with human-health benchmarks were present at high or moderate concentrations in 69 percent of the Basin and Range basin-fill aquifer study area. The distribution, however, varied from a low of 30 percent in Utah/Idaho to a high of 82 percent in California; the distribution in Nevada and Arizona, 75 and 71 percent, respectively, were similar to California. Individual constituents present at high or moderate concentrations were also not the same across the study area and varied by State. Arsenic, fluoride, molybdenum, manganese, and uranium exceeded human-health benchmarks for some samples in California and Arizona (generally the southern part of the study area), whereas only arsenic exceeded human-health based benchmarks in Nevada and Utah/Idaho (generally the northern part of the study area). There were no high or moderate concentrations of fluoride or uranium in samples from Nevada and Utah/Idaho and only low or moderate concentrations of molybdenum and manganese. These differences in water quality across the multistate study area could reflect differences in the composition of rocks and sediments that compose the aquifers, the distribution of developed land uses, and other factors.

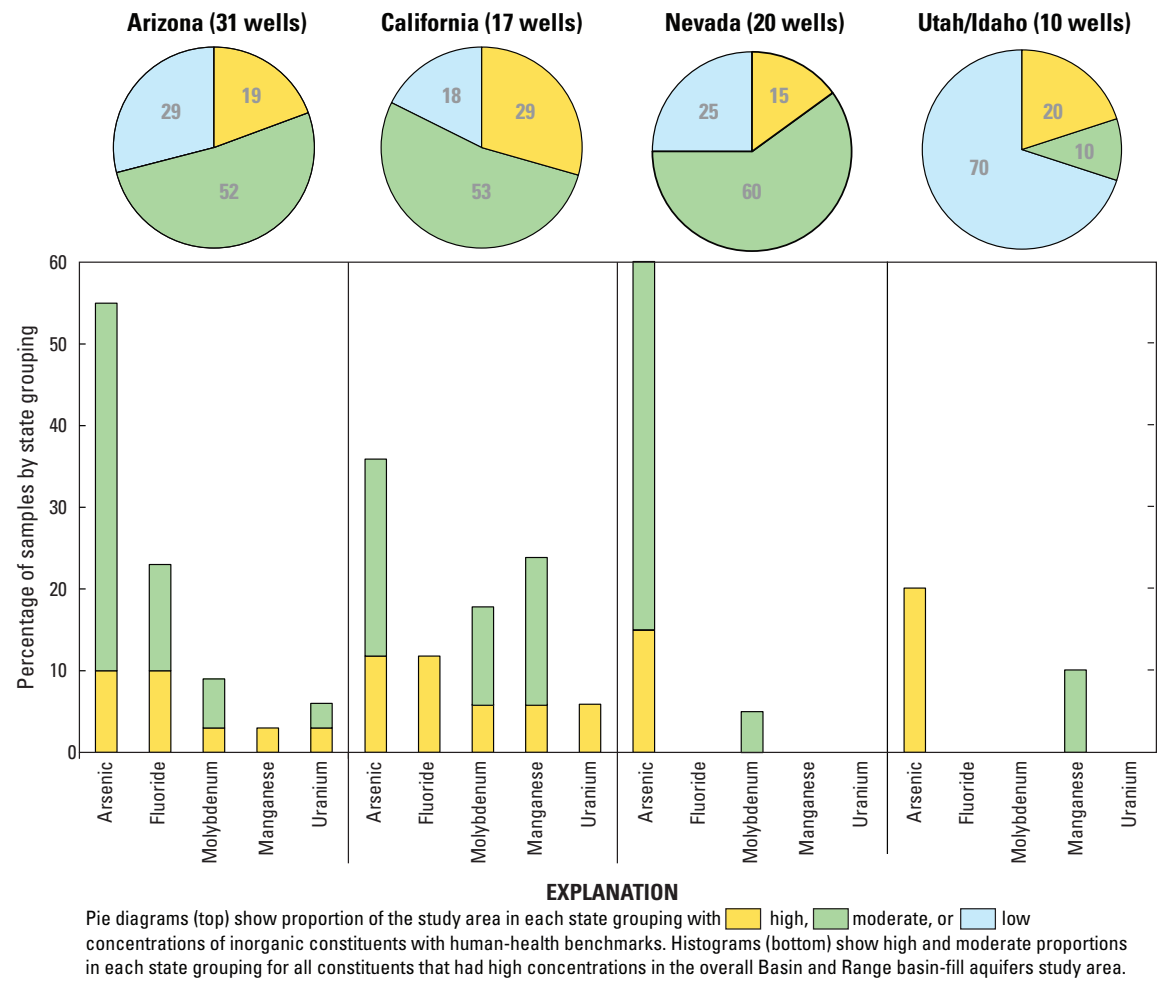

By MaryLynn Musgrove and Kenneth Belitz

\section{SELECTED REFERENCES}

Anning, D.W., and Konieczki, A.D., 2005, Classification of hydrogeologic areas and hydrogeologic flow systems in the Basin and Range physiographic province, Southwestern United States: U.S. Geological Survey Professional Paper 1702, 37 p., 2 pl., http://pubs.usgs.gov/pp/2005/pp1702/.

Arnold, T.L., DeSimone, L.A., Bexfield, L.M., Lindsey, B.D., Barlow, J.R., Kulongoski, J.T., Musgrove, M., Kingsbury, J.A., and Belitz, K., 2016, Groundwater quality data from the National Water-Quality Assessment Project, May 2012 through December 2013: U.S. Geological Survey Data Series 997, 56 p., http://dx.doi.org/10.3133/ds997.

Belitz, K., Jurgens, B., Landon, M.K., Fram, M.S., and Johnson, T., 2010, Estimation of aquifer scale proportion using equal area grids: Assessment of regional scale groundwater quality: Water Resources Research., v. 46, 14 p., http://dx.doi.org/10.1029/2010WR009321.

Burow, K.R., and Belitz, K., 2014, Groundwater studies—Principal aquifer surveys: U.S. Geological Survey Fact Sheet 2014-3024, 2 p., http://dx.doi.org/10.3133/fs20143024

DeSimone, L.A., McMahon, P.B., and Rosen, M.R., 2014, The quality of our Nation's waters - Water quality in principal aquifers of the United States, 1991-2010: U.S. Geological Survey Circular 1360, 151 p., http://dx.doi.org/10.3133/cir1360.

Robson, S.G., and Banta, E.R., 1995, Ground water atlas of the United States—segment 2, Arizona, Colorado, New Mexico, Utah: U.S. Geological Survey Hydrologic Atlas 730-C, http://pubs.usgs.gov/ha/ha730/ch_c/index.html.

Thiros, S.A., Paul, A.P., Bexfield, L.M., and Anning, D.W., 2014, The quality of our Nation's waters-Water quality in the basinfill aquifers of the southwestern United States: Arizona, California, Colorado, Nevada, New Mexico, and Utah, 1993-2009: U.S. Geological Survey Circular 1358, 113 p., http://dx.doi.org/10.3133/cir1358.

Toccalino, P.L., Norman, J.E., Phillips, R.H., Kauffman, L.J., Stackelberg, P.E., Nowell, L.H., Krietzman, S.J., and Post, G.B., 2004, Application of health-based screening levels to ground-water quality data in a state-scale pilot effort: U.S. Geological Survey Scientific Investigations Report 2004-5174, 64 p., http://pubs.usgs.gov/sir/2004/5174/.

Toccalino, P.L., Norman, J.E., and Schoephoester, K.M., 2014, Health-based screening levels for evaluating water-quality data, http://water.usgs.gov/nawqa/HBSL, doi:10.5066/F71C1TWP

Walvoord, M.A., Phillips, F.M., Stonestrom, D.A., Evans, R.D., Hartsough, P.C., Newman, B.D., and Striegl, R.G., 2003, A reservoir of nitrate beneath desert soils: Science, v. 302, no. 5647, p. 1021-1024.

\section{Principal Aquifer Studies}

The USGS NAWQA Project has been assessing the quality of groundwater since 1991. The NAWQA studies include Land Use Studies (LUS), Major Aquifer Studies (MAS), and Principal Aquifer Studies (PAS). These three study types are based on sampling networks of wells distributed across an area of interest. The LUS networks typically consist of observation wells that are relatively shallow; MAS networks typically consist of domestic-supply wells that are intermediate in depth; and PAS networks typically consist of public-supply wells that are relatively deep. A national synthesis of shallow and intermediate depth groundwater quality was reported by DeSimone and others (2014). A regional synthesis of water quality for basin-fill aquifers of the Southwest, including the Basin and Range basin-fill aquifers was reported by Thiros and others (2014). This fact sheet provides a summary of PAS data for 78 public-supply wells sampled in 2013 in the Basin and Range basin-fill aquifers (data available in Arnold and others, 2016).

The PAS assessments like this one allow for the comparison of constituent concentrations in untreated groundwater with benchmarks established for the protection of human health and for aesthetic qualities of drinking water and also provide a basis for comparison of groundwater quality among the principal aquifers.

The data collected by NAWQA include chemical analyses generally not available as part of regulatory compliance monitoring, including measurements at concentrations much lower than the levels used as human-health benchmarks, and measurements of constituents that can be used to trace the sources and movement of groundwater.

\section{For more information}

Technical reports and hydrologic data collected for the USGS NAWQA Project may be obtained from:

NAWQA Chief Scientist

U.S. Geological Survey

12201 Sunrise Valley Drive, MS 413

Reston, VA 20192-0002

Email: nawqapublicinfo@usgs.gov

WEB: http://water.usgs.gov/nawqa/ 